\title{
The Relationship between Blood Pressure Level and Serum Uric Acid Level in Chronic Hemodialysis Patients
}

\author{
MOHAMMED F.F. ATIA, M.Sc.*; SAMY A. KHODEIR, M.D.*; MABROUK R. AL-SHEIKH, M.D.* and \\ GHADA A. SOLIMAN, M.D.** \\ The Departments of Internal Medicine* and Clinical Pathology**, Faculty of Medicine, Tanta University
}

\begin{abstract}
Background: In this study we are going to discuss the relationship between blood pressure level and serum uric acid level in chronic hemodialysis patients.

Aim of the Work: Evaluation of the relation between blood pressure level and serum uric acid level in chronic hemodialysis patients.

Subjects and Methods: The cross-sectional study was conducted at Tanta university Hospital from January 2016 to June 2016, and comprised 200 CKD patients on regular hemodialysis. Blood pressure was measured just before and after dialysis and every one hour during dialysis in 3 consecutive sessions. Uric acid levels were measured just before and after hemodialysis.
\end{abstract}

Results: Of the 200 patients, odds ratio for high uric acid level in the group with predialysis systolic hypertension was 0.363 (95\% CI: $0.148-0.893 ; p=0.027)$, for predialysis diastolic hypertension was $0.652(95 \% \mathrm{CI}: 0.192-1.523 ; p=0.126)$ and 0.528 (95\% CI: $0.357-1.754 ; p=0.213$ ) for intradialysis hypotension.

Conclusion: This study showed paradoxical association between high uric acid level and high systolic blood pressure.

Key Words: Kidney disease - Blood pressure - Hemodialysis.

\section{Introduction}

THERE is strong relationship between serum uric acid level and hypertension [1]. Uric acid acts as antioxidant against inflammatory cells and also maintains vascular dilatation during oxidative stress [1]. Meanwhile hyperuricemia can cause hypertension, metabolic syndrome and cardiovascular diseases [2]

The pathogenesis of uric acid induced hypertension had been studied in rats and humans and

Correspondence to: Dr. Mohammed F.F. Atia, The Department of Internal Medicine, Faculty of Medicine, Tanta University includes endothelial dysfunction, decreased levels of serum nitrites, increased renin and decreased nitric oxide synthase expression in kidney and renal arteriolar vasoconstriction [3].

Uric acid is a small molecule that can be partially removed by hemodialysis as for urea. Paradoxical results were gained between hyperuricemia and outcomes in chronic kidney disease (CKD) patients [4]

Hypertension is a common finding in hemodialysis patients, occurring in $75 \%$ of them and it is a significant factor in cardiovascular disease, stroke and renal failure [5]. Wide pulse pressure and intra dialysis hypotension are also associated with increased long-term mortality in dialysis patients [6]

The role of uric acid in hypertension in endstage renal disease (ESRD) was studied once in Silverstein colleague and showed a positive relationship between high uric acid and hypertension in pediatric hemodialysis patients [7].

\section{Patients and Methods}

The study was conducted in hemodialysis unit at Tanta University Hospital at period from January 2016 to June 2016. The study was conducted crosssectional (observational) approach to study the relation between blood pressure level and serum uric acid level in patients on chronic hemodialysis.

\section{Inclusion criteria:}

Patients on chronic regular hemodialysis for more than 6 months.

\section{Exclusion criteria:}

Patients on treatment for hyperuricemia, patients with history of myeloproliferative disease, patients on diuretics. 


\section{Clinical and laboratory assessment:}

\section{All patients were subjected to:}

1-Full history taking: Baseline information about the socioeconomic and demographic data (age, sex, weight, height, body mass index, occupation, marital status and smoking). Complete clinical examination; Blood pressure was measured just before and after session and every one hour during session in 3 consecutive sessions.

2-Laboratory investigations including: BUN before and after dialysis, Serum uric acid before and after dialysis session. Principle of the method of serum uric acid [8]. Uric acid is oxidized by uricase to allantoine and hydrogen peroxide $(2 \mathrm{H} 2 \mathrm{O} 2)$, which under the influence of POD, 4-aminophenazone (4-AP) and 2-4 Dichlorophenol sulfonate (DCPS) forms a red quinoneimine compound.

\section{Statistical analysis:}

Statistical presentation and analysis of the present study was conducted, using the mean, standard deviation, Chi-square and Linear Correlation Coefficient.

Chi-square is the hypothesis that the row and column variables are independent, without indicating strength or direction of the relationship. Linear Correlation coefficient was used for detection of correlation between two quantitative variables in one group. A p value of less than 0.05 was considered statistically significant.

\section{Results der: \\ I- Demographic data Regarding age and gen-}

This study included 77 (38.5\%) males and 123 $(61.5 \%)$ females as shown in Table (1), the range of age was $19-75$ years with mean $49.77 \pm 13.07$ as shown in Table (2).

II- Clinical data: The studied patients had BMI range 20 - 31 with mean $25.30 \pm 2.18$ as shown in Table (3). As illustrated in Table (4), the studied patients showed pre-dialysis systolic blood pressure ranging from $93-180$ with mean $130.91 \pm 17.52$.

Pre- dialysis diastolic blood pressure had range 57-103 with mean 81.01 \pm 9.0 as shown in Table (5).

III- Laboratory Data: The average pre-dialysis uric acid level was $6.56 \pm 1.85 \mathrm{mg} / \mathrm{dl}$ with range 2.9-13.9as shown in Table (6).
The average post-dialysis uric acid was $3.2 \pm$ $2.24 \mathrm{mg} / \mathrm{dl}$ with range $0.5-7.3$ as shown in Table (7).

Thirty five patients out of $88(39.8 \%)$ who had pre-dialysis systolic hypertension showed serum uric acid $\geq 6$, while 53 patients $(60.2 \%)$ had serum uric acid $<6$ with statistical significance $(p=0.001)$ for each group, these results is illustrated Table (8) and Fig. (1).

Fifteen patients out of $44(34.1 \%)$ who had prediastolic hypertension showed serum uric acid $\geq 6$, while 29 patients $(65.9 \%)$ had serum uric acid $<6$ with statistical significance $(p=0.001)$ for each group, these data is illustrated in Table (9) and Fig. (2).

Fifty three patients out of 120 (44.2\%) who had intra dialysis hypotension showed serum uric acid $\geq 6$, while 67 patients $(55.8 \%)$ had serum uric acid $<6$ with statistical significance $(p=0.001)$ for each group as shown Table (10) and Fig. (3).

\section{Relation between uric acid and blood pressures:}

Odds ratio for high uric acid level in the group with pre-dialysis systolic hypertension was 0.363 (95\% CI: $0.148-0.893 ; p=0.027$ ), for pre-dialysis diastolic hypertension was 0.652 (95\% CI: $0.192-1.523 ; p=0.126)$ and 0.528 (95\% CI: $0.357-$ $1.754 ; p=0.213$ ) for intra-dialysis hypotension as shown in Table (11).

Table (1): Gender characters of the studied patients.

\begin{tabular}{llc}
\hline & $\mathrm{N}$ & $\%$ \\
\hline Male & 77 & 38.5 \\
Female & 123 & 61.5 \\
\hline Total & 200 & 100 \\
\hline
\end{tabular}

Table (2): Age characters of the studied patients.

\begin{tabular}{lll}
\hline & Range & Mean \pm S. D \\
\hline Age & $19-75$ & $49.77 \pm 13.07$ \\
\hline
\end{tabular}

Table (3): BMI of the studied patients

\begin{tabular}{llc}
\hline & Range & Mean \pm S. D \\
\hline BMI & $20-31$ & $25.30 \pm 2.18$ \\
\hline
\end{tabular}

Table (4): Pre- dialysis systolic blood pressure.

\begin{tabular}{lcc}
\hline & Range & Mean \pm S. D \\
\hline $\begin{array}{l}\text { Pre- dialysis systolic } \\
\text { blood pressure }\end{array}$ & $93-180$ & $130.91 \pm 17.52$ \\
\hline
\end{tabular}


Table (5): Pre- dialysis diastolic blood pressure.

\begin{tabular}{lcc}
\hline & Range & Mean \pm S. D \\
\hline $\begin{array}{l}\text { Pre-dialysis diastolic } \\
\text { blood pressure }\end{array}$ & $57-103$ & $81.01 \pm 9.0$ \\
\hline
\end{tabular}

Table (6): Pre-dialysis uric acid of patients.

\begin{tabular}{lcc}
\hline & Range & Mean \pm S. D \\
\hline Pre-dialysis uric acid level & $2.9-13.9$ & $6.56 \pm 1.58$ \\
\hline
\end{tabular}

Table (7): Post dialysis uric acid of patients.

\begin{tabular}{lcc}
\hline & Range & Mean \pm S. D \\
\hline Post-dialysis uric acid level & $0.5-7.3$ & $3.2 \pm 2.24$ \\
\hline
\end{tabular}

Table (8): Correlation between pre-dialysis systolic blood hypertension and pre-dialysis uric acid.

\begin{tabular}{|c|c|c|c|}
\hline \multirow{2}{*}{$\begin{array}{l}\text { Pre-dialysis systolic } \\
\text { blood hypertension }\end{array}$} & \multicolumn{2}{|c|}{ Uric acid } & \multirow{2}{*}{ Total } \\
\hline & $\geq 6(n=123)$ & $<6(\mathrm{n}=77)$ & \\
\hline \multicolumn{4}{|l|}{$\geq 140 \mathrm{~mm} \mathrm{Hg}$} \\
\hline $\mathrm{N}$ & 35 & 53 & 88 \\
\hline$\%$ & 39.8 & 60.2 & 100.0 \\
\hline \multicolumn{4}{|l|}{ Chi-square } \\
\hline $\begin{array}{l}\mathrm{X}^{2} \\
p \text {-value }\end{array}$ & \multicolumn{2}{|c|}{$0.001^{*}$} & \\
\hline
\end{tabular}

Statistically significant.

Table (9): Correlation between pre-dialysis diastolic hypertension and pre-dialysis uric acid.

\begin{tabular}{llll}
\hline & \multicolumn{2}{c}{ Uric acid } & \\
\cline { 2 - 3 } $\begin{array}{l}\text { Pre-dialysis diastolic } \\
\text { hypertension }\end{array}$ & $\geq 6(\mathrm{n}=123)$ & $<6(\mathrm{n}=77)$ & Total \\
\cline { 2 - 3 } & & 29 & 44 \\
\hline $90 \mathrm{~mm} \mathrm{Hg}$ & 15 & 65.9 & 100.0 \\
$\mathrm{~N}$ & 34.1 & & \\
$\%$ & & & \\
Chi-square & & 20.502 & \\
$\mathrm{X}^{2}$ & & $0.001^{*}$ & \\
$p^{\text {-value }}$ & & & \\
\hline
\end{tabular}

Statistically significant.

Table (10): Correlation between intra-dialysis hypotension and pre-dialysis uric acid.

\begin{tabular}{|c|c|c|c|}
\hline \multirow{2}{*}{$\begin{array}{l}\text { Intra-dialysis } \\
\text { hypotension }\end{array}$} & \multicolumn{2}{|c|}{ Uric } & \multirow{2}{*}{ Total } \\
\hline & $\geq 6(\mathrm{n}=123)$ & $<6(\mathrm{n}=77)$ & \\
\hline $\mathrm{N}$ & 53 & 67 & 120 \\
\hline$\%$ & 44.2 & 55.8 & 100.0 \\
\hline \multicolumn{4}{|l|}{ Chi-square } \\
\hline $\mathrm{X}^{2}$ & \multicolumn{2}{|c|}{38.072} & \\
\hline$p$-value & \multicolumn{2}{|c|}{$0.001^{*}$} & \\
\hline
\end{tabular}

Statistically significant.
Table (11): Association between uric acid and blood pressures.

\begin{tabular}{|c|c|c|c|c|}
\hline \multirow{2}{*}{ Variables } & \multirow{2}{*}{$\begin{array}{l}\text { Odds } \\
\text { ratio }\end{array}$} & \multicolumn{2}{|c|}{$95 \% \mathrm{CI}$} & \multirow{2}{*}{$\begin{array}{c}p- \\
\text { value }\end{array}$} \\
\hline & & Lower & Upper & \\
\hline $\begin{array}{l}\text { Pre-dialysis systolic } \\
\text { blood hypertension }\end{array}$ & 0.363 & 0.148 & 0.893 & 0.027 \\
\hline $\begin{array}{l}\text { Pre-dialysis diastolic } \\
\text { hypertension }\end{array}$ & 0.652 & 0.192 & 1.523 & 0.126 \\
\hline $\begin{array}{l}\text { Intra-dialysis } \\
\text { hypotension }\end{array}$ & 0.528 & 0.357 & 1.754 & 0.213 \\
\hline
\end{tabular}

Statistically significant.

Pre-dialysis systolic hypertension $\geq 140$

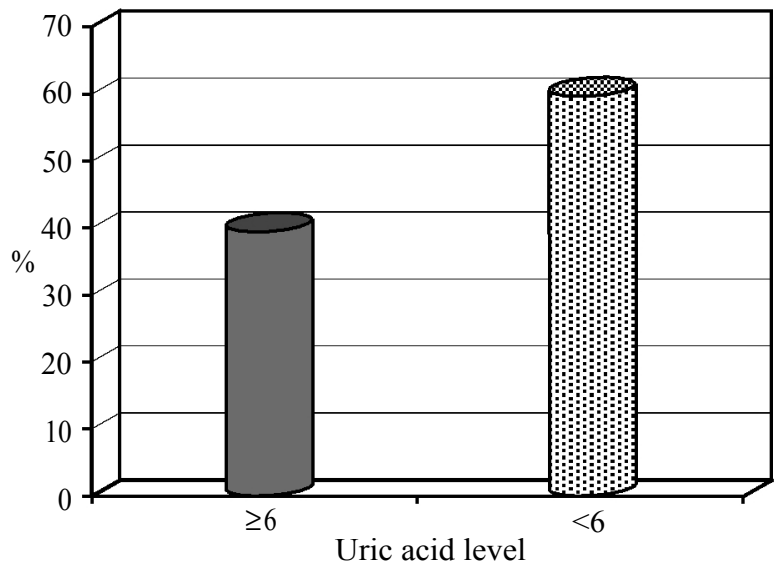

Uric acid level $\geq 6 \quad$ 堌 Uric acid level $<6$

Fig. (1): Correlation between pre-dialysis systolic blood pressure and pre-dialysis uric acid.

Pre-dialysis diastolic hypertension $\geq 90$

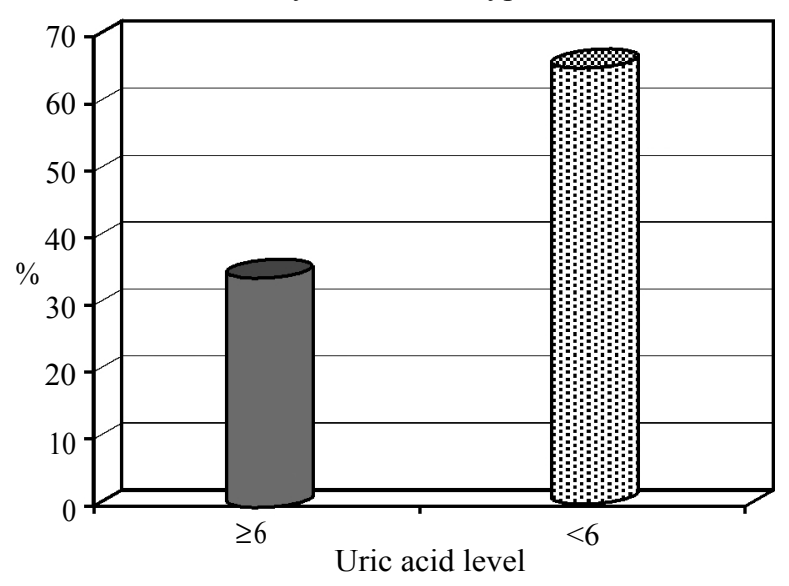

Uric acid level $\geq 6 \quad$ Uric acid level $<6$

Fig. (2): Correlation between pre-dialysis diastolic blood pressure and pre-dialysis uric acid. 

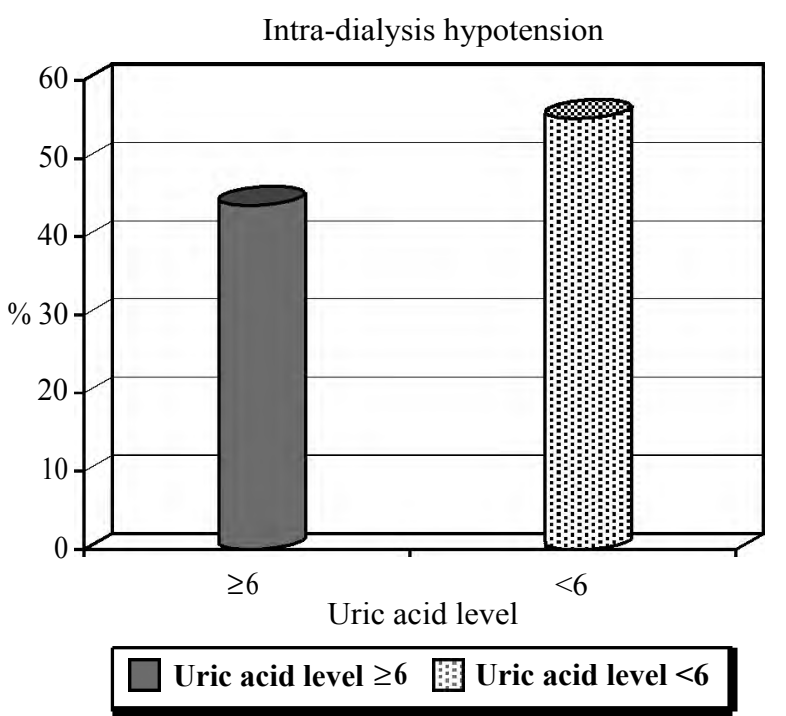

Fig. (3): Correlation between intra dialysis hypotension and pre-dialysis uric acid.

\section{Discussion}

Chronic Kidney Disease (CKD) is a worldwide public health problem with an estimated prevalence of 10 to $13 \%$ in high-income countries [9].

The KDOQI defines CKD as abnormalities of kidney structure or function, present for $>3$ months, with implications for health. CKD is classified based on cause, GFR category (G1-G5), and albuminuria category (A1-A3), abbreviated as CGA

Hypertension is a common finding in hemodialysis patients and it occurs in up to $85 \%$ of them [11]. In these patients multiple factors can cause high blood pressure including fluid overload, activation of rennin angiotensin-aldosterone axis or use of exogenous erythropoietin that make it difficult to evaluate the causative mechanism [12]

Hyperuricemia has long been associated with renal disease. Approximately 20 to $60 \%$ of patients with hyperuricemia have mild or moderate renal dysfunction [13].

The present study was conducted in the Nephrology Unit in Tanta University Hospital and was carried out on 200 patients.

Regarding to the age, the present work included $77(38.5 \%)$ males and $123(61.5 \%)$ females with the average age was $19-75$ years with mean $49.77 \pm 13.07$ years, Roozbeh et al., (2015) studied on $60(65.9 \%)$ males and $31(34.1 \%)$ females and the average age was $50.8 \pm 16.7$ years. Bae et al., (2016) [14]. who investigated the relation between lower serum uric acid level and mortality in dialysis patients stated that $45.2 \%$ were women and $54.8 \%$ were men and the mean age was $56 \pm 13$ years. This slight difference may be due to different sample size.

Regarding to the BMI, the mean BMI in this study was $25.30 \pm 2.18$, these were similar to Roozbeh et al., (2015) as it was $24.1 \pm 5.4$ and $22.8 \pm 3.3$ according to Bae et al. (2016).

Regarding to pre-dialysis serum uric acid, in this study pre-dialysis serum uric acid range was $2.913 .9 \mathrm{mg} / \mathrm{dl}$ with average $6.56 \pm 1.85 \mathrm{mg} / \mathrm{dl}$ while Roozbeh et al., (2015) stated that the average predialysis uric acid was $5.7 \pm 1.02 \mathrm{mg} / \mathrm{dl}$, the present study was in agreement with this study.

Regarding to the post dialysis serum uric acid, in this study the post dialysis serum uric acid range was $0.5-7.3 \mathrm{mg} / \mathrm{dl}$ with mean $3.2 \pm 2.24 \mathrm{mg} / \mathrm{dl}$, while in Roozbeh et al., (2015) only one patient had serum uric acid $\geq 6 \mathrm{mg} / \mathrm{dl}$, the present study was in agreement with this study as there is only 3 patients in the present study with serum uric acid $\geq 6 \mathrm{mg} / \mathrm{dl}$.

In this study, $123(61.5 \%)$ patients had predialysis serum uric acid $\geq 6 \mathrm{mg} / \mathrm{dl}$, on the other hand 40 (44\%) patients out of 91 in Roozbeh et al., (2015) had predialysis serum uric acid $\geq 6 \mathrm{mg} / \mathrm{dl}$, this difference may be due to different sample size.

Regarding to pre- dialysis systolic blood pressure. The studied patients showed pre-dialysis systolic blood pressure ranging from $93-180$ (mm $\mathrm{Hg}$ ) with mean $130.91 \pm 17.52(\mathrm{~mm} \mathrm{Hg})$ while those in Roozbeh et al. (2015) showed mean pre- dialysis systolic blood pressure $144.1 \pm 22.9$ (mm Hg), this was in agreement with the present study.

Regarding pre-dialysis diastolic blood pressure the range was 57-103 ( $\mathrm{mm} \mathrm{Hg})$ with mean 81.01 \pm 9.0 (mm Hg) while Roozbeh et al., (2015) showed mean pre-dialysis diastolic blood pressure 81.8 \pm 12.04 (mm Hg), this was in agreement with the present study.

Of all patients, 88 (44\%) had high predialysis systolic blood pressure. Also 44 (22\%) had high predialysis diastolic blood pressure. Roozbeh et al., (2015) declared that 55 (60.4\%) had high predialysis systolic blood pressure and $18(19.7 \%)$ had high predialysis diastolic blood pressure; this may be duo to different sample size.

As regard correlation between pre-dialysis systolic blood hypertension and pre-dialysis uric acid, this study illustrated that 35 (39.8\%) of patients who had pre-dialysis systolic blood hypertension $(\geq 140 \mathrm{~mm} \mathrm{Hg}$ ) had serum uric acid $\geq 6 \mathrm{mg} / \mathrm{dl}$ 
with statistical significance $(p=0.001)$, while in Roozbeh et al., (2015) study 19 (34.5\%) patients had serum uric acid $>6 \mathrm{mg} / \mathrm{dl}$, this was in agreement with the present study.

On the other hand, the correlation between predialysis diastolic hypertension and pre-dialysis uric acid level showed that 15 patients out of 44 (34.1\%) who had pre-diastolic hypertension (>90 $\mathrm{mm} \mathrm{Hg}$ ) showed serum uric acid $>6 \mathrm{mg} / \mathrm{dl}$, while 29 patients $(65.9 \%)$ had serum uric acid $<6 \mathrm{mg} / \mathrm{dl}$ with statistical significance $(p=0.001)$, Roozbeh et al., (2015) showed that $5(27.8 \%)$ patients had uric acid $>6 \mathrm{mg} / \mathrm{dl}$ and $13(72.2 \%)$ patients had serum uric acid $<6 \mathrm{mg} / \mathrm{dl}$, this was in agreement with the present study.

Regarding to intra dialysis hypotension. In the current study, 53 patients out of 120 (44.2\%) who had intra dialysis hypotension showed serum uric acid $>6 \mathrm{mg} / \mathrm{dl}$, while 67 patients $(55.8 \%)$ had serum uric acid $<6 \mathrm{mg} / \mathrm{dl}$ with statistical significance $(p=0.001)$, Roozbeh et al., (2015) showed that 25 $(41 \%)$ patients had serum uric acid $>6 \mathrm{mg} / \mathrm{dl}$ and $36(59 \%)$ patients had serum uric acid $<6 \mathrm{mg} / \mathrm{dl}$, this was in agreement with the present study.

The current study illustrated that odds ratio for high uric acid level in the group with predialysis systolic hypertension was 0.363 (95\% CI: 0.148 $0.893 ; p=0.027$ ), for pre-dialysis diastolic hypertension was 0.652 (95\% CI: $0.192-1.523 ; p=0.126)$ and 0.528 (95\% CI: $0.357-1.754 ; p=0.213$ ) for intra dialysis hypotension, this was in agreement with Roozbeh et al., (2015) which showed that odds ratio for high uric acid level in the group with pre-dialysis systolic hypertension was $0.352(95 \%$ CI: $0.147-0.844 ; p=0.01$ ); for predialysis diastolic hypertension was 0.407 (95\% CI: 0.0.131-1.25; $p=0.11$ ); and for intra dialysis hypotension was 0.648 (95\% CI: 0.266-1.577; $p=0.33$ ).

Our study showed that high uric acid level can be a marker of protection against high systolic blood pressure which causes increased hemodialysis mortality.

\section{Limitations of the study:}

- This study did not investigate the effect of lowering uric acid with drug on blood pressure.

- This study did not consider the effect of residual renal function on uric acid and blood pressure.

- This study did not include patients undergoing peritoneal dialysis.

\section{Conclusion:}

This study showed paradoxical association between high uric acid level and high systolic pressure in hemodialysis patients assuming that this relationship could be due to reverse epidemiology in dialysis patients, so tight control of high serum uric acid is not a classical recommendation.

Recommendations: Future studies considering the effect of residual renal function on uric acid and blood pressure are required. Future studies including dialysis efficacy and duration of dialysis and their effect on serum uric acid and blood pressure are required. Studies on the effect of lowering uric acid with drug on blood pressure would be of value. Tight control of elevated serum uric acid should not be classical recommendation in dialysis patients.

Acknowledgements: We would like to thank all participants who helped during this study.

Conflict of interest: None declared.

\section{References}

1- KHOSLA U.M., ZHARIKOV S., FINCH J., et al.: Hyperuricemia induces endothelial dysfunction. Kidney. Int., 67 (5): $1739-42$.

2- LIU W.C., HUNG C.C., CHEN S.C., et al.: Association of hyperuricemia with renal outcomes, cardiovascular disease, and mortality. Clin. J. Am. Soc. Nephrol., 7 (4): 541-8, 2012.

3- MAZZALI M., HUGHES J., KIM Y.G., et al.: Elevated Uric Acid Increases Blood Pressure in the Rat by a Novel Crystal-Independent Mechanism. Hypertension, 38 (5): 1101-6, 2001.

4- ROOZBEH J., SAGHEB M.M., VAFAIE E., et al.: The association between blood pressure level and serum uric acid concentration in hemodialysis patients. Journal of Nephropathology, 4 (3): 85, 2015.

5- LIU W.C., HUNG C.C., CHEN S.C., et al. (2012): Association of hyperuricemia with renal outcomes, cardiovascular disease, and mortality [abstract]. Clin. J. Am. Soc. Nephrol., 7 (4): 541-8.

6- AGARWAL R.: Hypertension and survival in chronic hemodialysis patients Past lessons and future opportunities. Kidney. Int., 67 (1): 1-13, 2005.

7- SILVERSTEIN D.M., SRIVATHS P.R., MATTISON P., et al.: Serum uric acid is associated with high blood pressure in pediatric hemodialysis patients. Pediatr. Nephrol., 26 (7): 1123-8.

8- CAL U.A.: Uric Acid. Uricase-POD. Liquid Ref.: URI016.

9- HERRERA-AÑAZCO P., TAYPE-RONDAN A., LAZOPORRAS M., et al.: Prevalence of chronic kidney disease in Peruvian primary care setting. BMC Nephrology, 18 (1): 246, 2017. 
10- EKNOYAN G., LAMEIRE N., BARSOUM R., et al.: The burden of kidney disease: Improving global outcomes. Kidney. Int., 66: 2089-2100, 2004.

11- MAHMOUD M. SALEM: Hypertension in the hemodialysis population: A survey of 649 patients. American Journal of Kidney Diseases, 26 (3): 461-468, 2017.

12- STURM G., KOLLERITS B., NEYER U., et al.: Uric acid as a risk factor for progression of non-diabetic chronic kidney disease? The Mild to Moderate Kidney Disease
(MMKD) Study. Experimental Gerontology, 43 (4): $347-$ 352,2008 .

13- KANG D.H., NAKAGAWA T., FENG L., et al.: A role for uric acid in the progression of renal disease. Journal of the American Society of Nephrology, 13 (12): 28882897, 2002.

14- BAE E., CHO, et al.: Lower serum uric acid level predicts mortality in dialysis patients. Medicine, 95 (24): e3701, 2016.

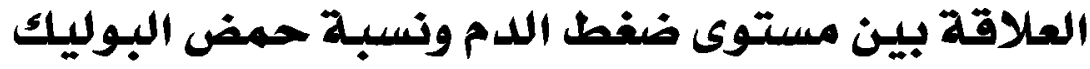 فى مصل الدم فى مرضى الغسيل فئوى الكلوى المستديم}

يوجد علاقة قوية بين مستوى حمض البوليك بالدم وضغط الدم. حمض البوليك عبارة عن جزئ صغير يتم إزالته جزئياً بواسطة الغسيل الكلوى.

يعمل حمض البوليك كمضاد للاكسدة فى البلازما ويحافظ على توسع الأوعية الدموية أثناء الاكسدة ولكن فى النسب المرتفعة يؤدى

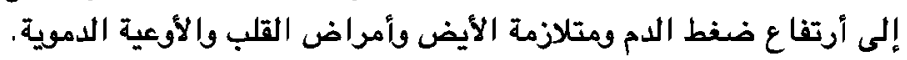

إن أرتفاع ضغط الدم منتشر فى مرضى الغسيل الكلوى بنسبة Vo بالمائة وهو مسبب أساسى فى أمراض الدم والسكتة الدماغية والفشل الكلوى.

يؤدى حمض البوليك إلى أرتفاع ضغط الدم عن طريق أختلاف وظائف الخلايا البطانية وأنقباض الشرايين الكلوية الصغيرة. البحث: أشتملت هذه الدراسة على مائتين مريض مصرى بالغسيل الكلوى المستديم فى مستشفي جامعة طنطا لمدة ستة أشهر.

$$
\text { معايير الإدراج: مرضى الغسيل الكلوى المستديم المنتظم لفترة تزيد عن } 7 \text { أثشهر. }
$$

معايير الأستبعاد : المرضى الذين يتعاطون علاج لأرتفاع نسبة حمض البوليك أو مدرات البول ومرضى أودام النخاع.

تم إجراء الفحوصات الآتية لكل المشاركين :

- تسجيل البيانات الأجتماعية والأقتصادية والديموغرافية.

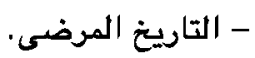

- الفحص الأكلينيكى: قياس الضغط قبل وبعد الغسيل وكل ساعة أثناء الغسيل لمدة ثلاث جلسات متتالية.

$$
\text { - الفحوصات المعملية وتشمل: بولينا وكرياتينين، حمض البوليك فى الدم قبل وبعد الغسيل. }
$$

النتائج: أظهرت النتائج أنخفاض فى ضغط الدم الأنقباضى ذو دلالة إحصائية في مرضى الغسيل الكلوى الذين يعانون من أرتفاع النياع

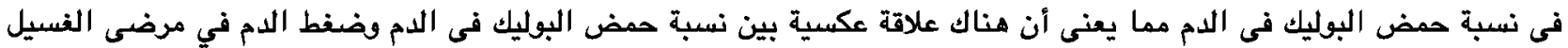

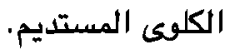

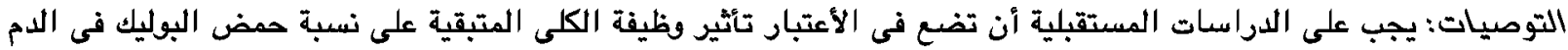

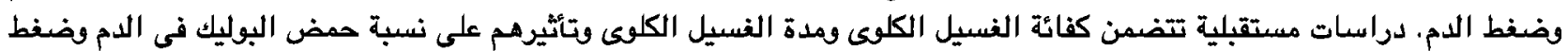

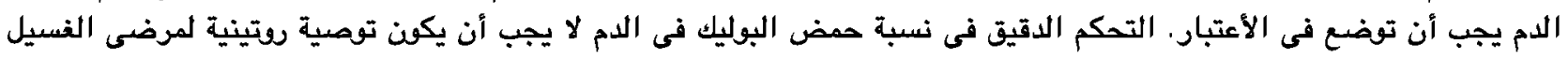

